\title{
Author Correction: Dynamics of oligomer populations formed during the aggregation of
} Alzheimer's A $\beta 42$ peptide

Thomas C. T. Michaels (D), Andela Šarić (D), Samo Curk, Katja Bernfur, Paolo Arosio, Georg Meisl (D), Alexander J. Dear, Samuel I. A. Cohen, Christopher M. Dobson, Michele Vendruscolo (D), Sara Linse (D) and Tuomas P. J. Knowles (DD

Correction to: Nature Chemistry https://doi.org/10.1038/s41557-020-0452-1, published online 13 April 2020.

In the version of this Article originally published, the affiliation for author Sara Linse was mistakenly given as Department of Chemistry and Applied Biosciences, ETH Zurich, Zurich, Switzerland; it should have been Department of Chemistry, Division for Biochemistry and Structural Biology, Lund University, Lund, Sweden. This has now been corrected.

Published online: 17 April 2020

https://doi.org/10.1038/s41557-020-0468-6

(C) The Author(s), under exclusive licence to Springer Nature Limited 2020 